\title{
Distribution and Diversity of Chlorophyceae in Saroornagar Lake, Hyderabad
}

\author{
*K T Padma Priya ${ }^{1}$, Y Seeta ${ }^{2}$ and P Manikya Reddy ${ }^{3}$ \\ ${ }^{I}$ Assistanat Professor, CVR College of Engineering, Ibrahimpatnam, Hyderabad, India \\ ${ }^{2}$ Research Scholar Department of Environmental Science, Osmania University, Hyderabad, India \\ ${ }^{3}$ Professor, CVR College of Engineering, Ibrahimpatnam, Hyderabad, India
}

\begin{abstract}
The present paper deals with the study of Chlorophyceae in Saroornagar Lake. Samples were collected from four sampling stations for a period of two years and comprehensive physico-chemical analysis was carried out. Linear multiple regression analysis (MRA) has been carried out in evaluating the importance of various physico-chemical variables on the growth and development of Chlorophyceae with SPSS software. The physico-chemical parameters played an important role in distribution and diversity of algae. Higher peaks of green algae were reported during summer and were represented by Chlorella vulgaris, Ankistrodesmusfalcatus, Scenedesmus sp. and Coelastrummicroporum. The species of Ankistrodesmusfalcatus, Chlorella vulgaris and Scenedesmus sp., Pandorinamorum, Actinastrumhantzchii, Pyrobotrysincurva and Micractiniumpusillum confirm eutrophic condition of the lake and act as indicators of organic pollution and represent pollution tolerant species. The indicator species of Chlorophyceae were represented by microphotographs.
\end{abstract}

Keywords: Chlorophyceae, diversity. physico-chemical parameters, pollution.

\section{Introduction}

Fresh water lakes are vital resources for any country and have greater prominence as they are linked to human welfare. They regulate the urban climate (Benjamin, 1996) and also have a prominent effect on ground water quality and ground water table (Ravikumar, 2013). Lakes have environmental significance as sources of surface and ground water recharge, maintain nutrient and energy exchange with watersheds and air sheds and support diversified aquatic life. Population growth, various human development activities, industrialization, urbanization, improper management of water resources, exploitation of catchment and command areas have led to severe water quality impairment. The value of the water is lost for many uses when it gets altered in its physical, chemical and biological properties (Rawal, 1978).Sewage discharge, improper agricultural practices and urban run offs leads to eutrophication of the inland water bodies and disrupt aquatic ecosystems. The deterioration and undesirable changes in physico-chemical and phycological characteristics of water body leads to water pollution which will ultimately effect the planktonic flora (Mishra, 1992). Green algae, blue green algae, diatoms, desmids and Euglenoid flagellates are the basic link in the food chain of all aquatic flora and were ecologically significant (Airsang, 2013). The present investigation involves distribution and diversity of Chlorococcales, influence of physico-chemical parameters on Chlorophyceae, representation of Chlorophyceae in the form of microphotographs and identification of algae as bio indicators in the Saroornagar Lake.

\section{Materials And Methods}

The water samples were collected on monthly intervals for a period of two years (September 2013 to August 2015) at four sampling stations in the lake. Priyadarshini Park, Pochamma temple, Singareni colony and Green park colony represent station I, II, III and IV respectively. The samples were analyzed as per the standard procedures of APHA (1995). For planktonic study the drop method of Pearsal (1946) was followed for frequency measurement. American optical binocular research microscope fitted with Cat Com Digital Image camera was used to take microphotograph of each specimen. The organisms were identified by following different monographs (Prescott 1968, and Gary E Dillard 2000). Linear MRA was employed to establish the interaction of physico-chemical parameters and Chlorophyceae. The proposed models contain the minimum number of variables, required to explain the variation of algal number to maximum extent in a statistically significant way. Percentage of variability is evaluated following the F-test to determine the good fit model. The regression equation is constructed with beta values and variables are excluded with backward regression. The most significant predictors will be elevated by forward step ward regression. 


\section{Results And Discussion}

The samples were collected and analyzed from the four sampling stations within the Saroornagar Lake on monthly intervals for a period of two years from September 2013 to August 2015. The average, maximum and minimum analytic results of each parameter during the period of investigation are summarized in Table 1.

TABLE 1: Ranges and average values of Physico-chemical parameters

All values are expressed in $\mathrm{mg} / \mathrm{L}$ except $\mathrm{pH}$ and Temp (OC)

\begin{tabular}{|c|c|c|c|c|c|c|c|c|c|c|c|c|c|}
\hline \multirow{3}{*}{ S.NO } & \multirow{3}{*}{ Parameters } & \multicolumn{3}{|l|}{ Station-I } & \multicolumn{3}{|c|}{ Station-II } & \multicolumn{3}{|c|}{ Station-III } & \multicolumn{3}{|c|}{ Station-IV } \\
\hline & & \multirow{2}{*}{ Average } & \multicolumn{2}{|l|}{ Range } & \multirow{2}{*}{ Average } & \multicolumn{2}{|c|}{ Range } & \multirow{2}{*}{ Average } & \multicolumn{2}{|l|}{ Range } & \multirow{2}{*}{ Average } & \multicolumn{2}{|l|}{ Range } \\
\hline & & & Min & Max & & Min & Max & & Min & Max & & Min & Max \\
\hline 1. & Temperature & 25.6 & 23.5 & 26.5 & 25.3 & 23.0 & 26.5 & 25.6 & 23.5 & 27.6 & 25.7 & 23.5 & 26.8 \\
\hline 2. & $\mathrm{pH}$ & 8.37 & 7.46 & 9.27 & 8.37 & 7.36 & 9.31 & 8.37 & 7.48 & 9.35 & 8.36 & 7.32 & 9.38 \\
\hline 3. & Carbonates & 22.3 & 27.0 & 38.0 & 20.8 & 25.0 & 36.0 & 23.2 & 28.0 & 38.0 & 18.3 & 26.0 & 36.0 \\
\hline 4. & Free $\mathrm{CO}_{2}$ & 0.86 & 2.2 & 4.4 & 0.91 & 2.2 & 6.6 & 0.91 & 2.2 & 4.4 & 1.46 & 2.2 & 8.8 \\
\hline 5. & Bicarbonates & 538.9 & 518.6 & 584.7 & 536.7 & 549.1 & 554.3 & 592.4 & 549.1 & 597.8 & 558.8 & 510.1 & 547.8 \\
\hline 6. & Chlorides & 581.1 & 574.5 & 550.0 & 559.5 & 597.6 & 587.0 & 556.3 & 539.0 & 550.9 & 559.8 & 574.5 & 587.0 \\
\hline 7. & DO & 0.6 & 0.2 & 2.4 & 0.5 & 0.2 & 2.4 & 0.5 & 0.2 & 2.6 & 0.3 & 0.2 & 2.4 \\
\hline 8. & BOD & 238.7 & 140.0 & 300.0 & 192.0 & 30.0 & 300.0 & 218.3 & 120.0 & 300.0 & 226.6 & 90.0 & 300.0 \\
\hline 9. & OM & 63.7 & 30 & 100 & 80.8 & 30 & 240 & 88.3 & 20 & 260 & 101.6 & 20 & 260 \\
\hline 10. & COD & 141.0 & 80.0 & 216.0 & 153.8 & 80.0 & 210.0 & 288.3 & 220.0 & 328.0 & 343.9 & 280.0 & 384.0 \\
\hline 11. & $\begin{array}{l}\text { Total } \\
\text { hardness }\end{array}$ & 648.0 & 552.0 & 832.0 & 602.4 & 500.0 & $750 . .0$ & 605.5 & 520.0 & 830.0 & 615.8 & 520.0 & 810.0 \\
\hline 12. & Calcium & 145.2 & 100.0 & 192.0 & 154.3 & 31.8 & 288.0 & 136.9 & 52.6 & 192.0 & 133.6 & 34.4 & 192.0 \\
\hline 13. & Magnesium & 51.7 & 17.0 & 94.8 & 53.2 & 14.1 & 102.1 & 57.8 & 29.2 & 99.8 & 60.8 & 29.2 & 126 \\
\hline 14. & Phosphates & 16.9 & 14.6 & 20.4 & 20.3 & 18.0 & 23.8 & 20.1 & 17.8 & 23.5 & 17.8 & 15.6 & 21.4 \\
\hline 15. & Silicates & 1.37 & 1.35 & 1.42 & 1.22 & 1.20 & 1.25 & 1.88 & 1.86 & 1.91 & 1.99 & 1.95 & 2.1 \\
\hline 16. & Sulphates & 247.7 & 238.0 & 260.0 & 257.7 & 248.0 & 270.0 & 255.7 & 246.0 & 268.0 & 252.9 & 243.0 & 265.0 \\
\hline 17. & Nitrates & 16.5 & 14.6 & 19.3 & 19.8 & 18.0 & 22.7 & 19.6 & 17.8 & 22.5 & 17.4 & 15.6 & 20.3 \\
\hline 18. & Nitrites & 1.07 & 0.92 & 1.15 & 1.54 & 1.46 & 1.62 & 1.09 & 1.02 & 1.13 & 1.43 & 1.36 & 1.53 \\
\hline 19. & Total Solids & 2814 & 2791 & 2845 & 2715 & 2691 & 2745 & 2755 & 2731 & 2785 & 2804 & 2781 & 2835 \\
\hline 20. & TDS & 2615 & 2582 & 2648 & 2521 & 2491 & 2638 & 2556 & 2531 & 2584 & 2606 & 2584 & 2638 \\
\hline
\end{tabular}

From the table it is evident that the physico-chemical parameters such as chlorides, total hardness, calcium, magnesium, phosphates, sulphates, BOD, total solids and total dissolved solids were higher than permissible limits and dissolved oxygen is in very low concentration in the lake. The $\mathrm{pH}$ is an important factor for plankton growth (Chisty, 2002) and also influence survival and nourishment of biological life. The $\mathrm{pH}$ of the lake is 8.37 and represents alkaline nature of the lake. Alkaline nature of the lakes in India was reported by Altaf H. Ganai (2014) and Ratna V Airsang (2015).

The high values of bicarbonates $\left(\mathrm{HCO}_{3}^{-}\right)$at all stations can be attributed to increase in organic decomposition during which $\mathrm{CO}_{2}$ is released which reacts to form bicarbonates. Similar observation was made by Mahadev and Hosamani (2010) and Airsang (2013). Chloride $\left(\mathrm{Cl}^{-}\right)$indicates the presence of high organic matter and plays a very important role to determine water quality. Higher chloride concentration represents high degree of pollution (Ameetha Sinha, 2014 and John Mohammad, 2015) and is the very important parameter to determine the water quality.

The present investigation revealed very low values of dissolved oxygen and very high values of biological oxygen demand (BOD) were recorded at all stations. Higher BOD values indicate the decomposition and mineralization of organic matter, high nutrient loading and organic pollution. Similar observation was made by Suresh (2015). Chemical oxygen demand(COD) is a reliable parameter for judging the extent of pollution in water (Amirkolaie, 2008). This may be due to inorganic matter from domestic sewage and oxidation of the organic waste by natural microorganisms (KundurSurender Reddy, 2014).The total hardness (TH) of the lake was very high compared to their permissible limit of BIS (1998). High hardness may be due to addition of detergents or sewage contamination.

In the present observation high values of phosphates $\left(\mathrm{PO}_{4}{ }^{3-}\right)$ and sulphates $\left(\mathrm{SO}_{4}{ }^{2-}\right)$ confirms the lake receiving sewage influx (Amin Hossaini, 2013).Total dissolved solids were higher than BIS permissible limits of $2000 \mathrm{mg} / \mathrm{L}$. The major sources of total solids in the water body are domestic sewage, detergents, runoff, leaching of substances from rocks in surrounding area and may also be attributed to the catchments watershed.

The lake chiefly represented by Chlorococcales, less number of Volvocales and complete absence of desmids. The total absence of desmids in the present investigation proves that the high degree of pollution and very poor water quality. This is in conformity with Hosmani (2002) who reported the absence of desmids is an 
indication of heavy pollution of water. The species is represented by Chlorella vulgaris, Ankistrodesmusfalcatus, Coelastrummicroporum, Crucigeniaqudrata, C. rectangularis, S. quadricauda, S. dimorphus, S. quadricauda var. quadrispina, Actinastrumhantzchiiand Micractiniumpusillum. Pandorinamorumand Pyrobotrys incurve were the species of Volvocales which was represented.

Chlorophyceae found in maximum numbers in summer and monsoon. Summer bloom of Chlorella vulgaris, Coelastrummicroporumand Scenedesmus sp. was observed. Ankistrodesmusfalcatusbloom was found during summer and monsoon. The lowest peaks were observed in winter and represented by the bloom of Crucigenia sp.

The Linear MRA reveals the $\mathrm{R}^{2}$ value for all the 20 independent factors is 0.963 at station I, 0.901 at station II, 0.968 at station III and 0.973 at station IV respectively. The best regression model obtained by backward elimination method represented the factors accounting algal variance significantly and eliminated insignificant factors. The coefficients in the best model are given in Table 2, 3, 4 and 5 and the best regression model obtained by backward elimination method is given by equation 1, 2, 3 and 4 at Station I, II, III and IV respectively.

At station I, Chlorococcales occurred in high numbers in the first year of investigation during June, July and September and in the second year of investigation during May, June and September. In both the years of investigation green algae were found in low numbers from November to January and also in the month of August. The Linear MRA analysis reveals that all the physico-chemical factors together account for 96.3\% variation in algae (Table 2) Among them temperature, $\mathrm{pH}$, Free $\mathrm{CO}_{2}$, chlorides, DO, BOD, $\mathrm{TH}$, phosphates, silica, nitrites $\left(\mathrm{NO}_{2}^{-}\right)$and nitrates $\left(\mathrm{NO}_{3}{ }^{-}\right)$are the minimum factors that could influence the growth of green algae to the maximum extent of $95 \%$.Temperature (Temp), $\mathrm{pH}$, Free $\mathrm{CO}_{2}$ and phosphates are found to be exerting significant negative influence on the growth of Chlorophyceae at $1 \%$ level and DO at $5 \%$ level. The indirect relationship of temperature and algae is reported by Ananthaiah (2010).The positive relationship of chlorides and the negative influence of $\mathrm{pH}$, DO, phosphates on algal growth is observed by TarakeshwarSenapati (2011) and Suresh (2015).Chlorides and BOD exhibited strong positive influence at $1 \%$ level, total hardness at 5\% level and nitrates at 8\% level. Direct relationship of BOD and Chlorococcales is reported by Sudha Rani (2004). In accordance to Agale (2013) total hardness positively influences the density of Chlorococcales.

Table 2: Multiple Regression Analysis of Physico-Chemical Factors on Chlorophyceae at Station I Coefficients ${ }^{a, b}$

\begin{tabular}{|c|c|c|c|c|c|c|}
\hline & \multirow[t]{2}{*}{ Model } & \multicolumn{2}{|c|}{ Unstandardized Coefficients } & \multirow{2}{*}{$\begin{array}{c}\text { Standardized } \\
\text { Coefficients } \\
\text { Beta } \\
\end{array}$} & \multirow[t]{2}{*}{$\mathbf{T}$} & \multirow[t]{2}{*}{ Sig. } \\
\hline & & B & Std. Error & & & \\
\hline \multirow{12}{*}{10} & (Constant) & 60018.044 & 10522.210 & & 5.704 & .000 \\
\hline & Temp & -723.285 & 95.498 & -.586 & -7.574 & .000 \\
\hline & $\mathrm{pH}$ & -949.771 & 308.342 & -.383 & -3.080 & .010 \\
\hline & FreeCO 2 & -394.048 & 114.573 & -.439 & -3.439 & .005 \\
\hline & $\mathrm{Cl}^{-}$ & 12.560 & 2.513 & .523 & 4.997 & .000 \\
\hline & $\mathrm{DO}$ & -587.089 & 241.556 & -.324 & -2.430 & .032 \\
\hline & BOD & 19.789 & 4.214 & .749 & 4.696 & .001 \\
\hline & TH & 4.190 & 1.695 & .241 & 2.472 & .029 \\
\hline & $\mathrm{PO}_{4}{ }^{3-}$ & -789.594 & 211.896 & -1.148 & -3.726 & .003 \\
\hline & $\mathrm{SiO}_{2}$ & -24092.939 & 5655.62 & -.356 & -4.260 & .001 \\
\hline & $\mathrm{NO}_{3}^{-}$ & 511.087 & 266.907 & .530 & 1.915 & .080 \\
\hline & $\mathrm{NO}_{2}^{-}$ & -9326.262 & 1961.902 & -.541 & -4.754 & .000 \\
\hline
\end{tabular}
$\begin{aligned} \mathrm{CP}= & 600018.044-723.285 \mathrm{Temp}-949.771 \mathrm{pH}-394.048 \mathrm{FreeCO}_{2}+12.560 \mathrm{Cl}^{-}-587.089 \mathrm{DO}+19.789 \mathrm{BOD} \\ & +4.190 \mathrm{TH}-789.594 \mathrm{PO}_{4}{ }^{3-}-24092.939 \mathrm{SiO}_{2}+511.087 \mathrm{NO}_{3}^{-}-9326.262 \mathrm{NO}_{2}\end{aligned}$

At station II, the Chlorococcales attained high numbers during monsoon throughout the investigation period. Their presence is comparatively low during winter.The Linear MRA analysis at this station reveals, all the physico-chemical factors together account for $90.1 \%$ of algal variance in a statistically significant manner. Temperature, carbonates, chlorides, DO, TH, calcium, phosphates, TS and Free $\mathrm{CO}_{2}$ are the minimum factors that could influence the growth of green algae to the maximum extent of 83.9\%.Carbonates, chlorides and total hardness influence the growth of Chlorophyceae positively at $1 \%$ level and total solids at 5\% level. Temperature, DO, calcium, phosphates negative influence at $1 \%$ level. The negative influence of calcium on the growth and abundance of Chlorophyceae was reported by Sudha Rani (2004) and Airsang (2013).The highest peaks of Chlorococcales are associated with deficiency of calcium at station II. 
Table 3: Multiple Regression Analysis of Physico-Chemical Factors on Chlorophyceae at Station II Coefficients ${ }^{\mathrm{a}, \mathrm{b}}$

\begin{tabular}{|c|c|c|c|c|c|c|}
\hline & \multirow[t]{2}{*}{ Model } & \multicolumn{2}{|c|}{ Unstandardized Coefficients } & \multirow{2}{*}{$\begin{array}{c}\begin{array}{c}\text { Standardized } \\
\text { Coefficients }\end{array} \\
\text { Beta }\end{array}$} & \multirow[t]{2}{*}{$\mathbf{t}$} & \multirow[t]{2}{*}{ Sig. } \\
\hline & & B & Std. Error & & & \\
\hline \multirow{10}{*}{12} & (Constant) & -32304.873 & 18158.752 & & -1.779 & .097 \\
\hline & Temp & -350.506 & 84.847 & -.505 & -4.131 & .001 \\
\hline & $\mathrm{CO}_{3}^{2-}$ & 37.822 & 12.671 & .708 & 2.985 & .010 \\
\hline & FreeCO $\mathrm{CO}_{2}$ & 253.203 & 120.530 & .575 & 2.101 & .054 \\
\hline & $\mathrm{Cl}^{-}$ & 4.335 & 1.537 & .440 & 2.821 & .014 \\
\hline & DO & -527.551 & 142.475 & -.586 & -3.703 & .002 \\
\hline & $\mathrm{TH}$ & 5.725 & 1.575 & .528 & 3.635 & .003 \\
\hline & $\mathrm{Ca}^{2+}$ & -10.422 & 2.334 & -.745 & -4.466 & .001 \\
\hline & $\mathrm{PO}_{4}^{3-}$ & -225.156 & 67.547 & -.574 & -3.333 & .005 \\
\hline & TS & 15.235 & 7.026 & .377 & 2.168 & .048 \\
\hline
\end{tabular}

At station III, high peaks were noticed during June and July in the first year, May and June in the second year of investigation. They were recorded low during winter. Linear MRA revealed all the factors together constitute $96.8 \%$ of algal variance significantly. Among them Free $\mathrm{CO}_{2}$, chlorides, organic matter, sulphates and nitrites are the minimum factors that explain the variation in Chlorococcales to the maximum extent of $86.9 \%$.Organic matter and chlorides accounted a strong positive significance at $1 \%$ level. Organic matter positively influencing algal growth was reported by Ananthaiah (2010). Free $\mathrm{CO}_{2}$, sulphates and nitrites exhibited negative influence at $1 \%$ level (Table $8 \mathrm{c}$ ). The growth of Chlorococcales was positively influenced by phosphates and nitrates at 5\% level. Phosphates accounted for $18 \%$ algal variance at $1 \%$ level and nitrates exhibited $17 \%$ of algal variance at $5 \%$ level. Similar relationship between green algae, phosphates and nitrates was observed by Malik (2014).

TABLE 4: Multiple Regression Analysis of Physico-Chemical Factors on Chlorophyceae at Station III

Coefficients ${ }^{\mathrm{a}, \mathrm{b}}$

\begin{tabular}{|c|c|c|c|c|c|c|}
\hline \multicolumn{2}{|c|}{ Model } & \multicolumn{2}{|c|}{ Unstandardized Coefficients } & $\begin{array}{c}\text { Standardized } \\
\text { Coefficients }\end{array}$ & \multirow{2}{*}{$\mathrm{t}$} & \multirow{2}{*}{ Sig. } \\
\cline { 3 - 7 } & (Constant) & 35112.089 & 10562.928 & & 3.324 & .004 \\
\hline \multirow{4}{*}{16} & $\mathrm{FreeCO}_{2}$ & -178.172 & 78.341 & -.212 & -2.274 & .035 \\
\cline { 2 - 7 } & $\mathrm{Cl}^{-}$ & 12.463 & 2.663 & .449 & 4.680 & .000 \\
\cline { 2 - 7 } & $\mathrm{OM}^{2}$ & 15.301 & 2.421 & .655 & 6.321 & .000 \\
\cline { 2 - 7 } & $\mathrm{SO}_{4}{ }^{-2}$ & -85.593 & 25.061 & -.416 & -3.415 & .003 \\
\cline { 2 - 7 } & $\mathrm{NO}_{2}{ }^{-}$ & -20278.060 & 5185.380 & -.564 & -3.911 & .001 \\
\hline
\end{tabular}

$\mathrm{CP}=35112.089-178.172$ Free $\mathrm{CO}_{2}+12.463 \mathrm{Cl}^{-}+15.301 \mathrm{OM}-85.593 \mathrm{SO}_{4}{ }^{2-}-20278.060 \mathrm{NO}_{2}{ }^{-}$

At station IV, high peaks were observed during March to June and low during winter. All the physicochemical factors together account for $97.3 \%$ of algal variance in a statistically significant manner. The factors which statistically influence the algal variance significantly are up to $85.7 \%$ according to linear MRA are $\mathrm{pH}$, carbonates, Free $\mathrm{CO}_{2}, \mathrm{OM}$, sulphates and nitrites.Carbonates, Free $\mathrm{CO}_{2}, \mathrm{OM}$ and sulphates are found to be exerting strong positive significance at $1 \%$ level and $\mathrm{pH}$ showed negative significance at $1 \%$ level (Table $8 \mathrm{~d}$ ). The indirect relation of alkalinity and algal growth was reported by TarakeshwarSenapati (2011), Ratna V Airsang (2013) and Suresh (2015). Carbonates positively influencing the growth of Chlorophyceae were repoted by Ananthaiah (2010). 
TABLE 5: Multiple Regression Analysis of Physico-Chemical Factors on Chlorophyceae at Station IV Coefficients ${ }^{\mathrm{a}, \mathrm{b}}$

\begin{tabular}{|c|c|c|c|c|c|c|}
\hline \multicolumn{2}{|c|}{ Coefficients } & \multicolumn{2}{|c|}{ Unstandardized Coefficients } & $\begin{array}{c}\text { Standardized } \\
\text { Coefficients }\end{array}$ & \multirow{2}{*}{$\mathrm{t}$} & \multirow{2}{*}{ Sig. } \\
\cline { 3 - 7 } & & $\mathrm{B}$ & Std. Error & Beta & & \\
\hline \multirow{4}{*}{15} & (Constant) & -6498.838 & 8132.316 & & -.799 & .435 \\
\cline { 2 - 7 } & $\mathrm{pH}$ & -2458.909 & 607.418 & -1.076 & -4.048 & .001 \\
\cline { 2 - 7 } & $\mathrm{CO}_{3}{ }^{2-}$ & 167.490 & 28.009 & 2.010 & 5.980 & .000 \\
\cline { 2 - 7 } & $\mathrm{FreeCO} 2$ & 494.263 & 124.480 & .822 & 3.971 & .001 \\
\cline { 2 - 7 } & $\mathrm{OM}^{2}$ & 7.814 & 2.163 & .475 & 3.612 & .002 \\
\cline { 2 - 7 } & $\mathrm{SO}_{4}^{2-}$ & 133.318 & 25.705 & .662 & 5.187 & .000 \\
\cline { 2 - 7 } & $\mathrm{NO}_{2}{ }^{-}$ & -6480.050 & 3314.655 & -.231 & -1.955 & .067 \\
\hline
\end{tabular}

a. station = STATION IV, b. Dependent Variable: Chlorophyceae $(\mathrm{CP})$

$$
\begin{aligned}
\mathrm{CP}= & -6498.838-2458.909 \mathrm{pH}+167.490 \mathrm{CO}_{3}{ }^{2-}+494.263 \text { Free } \mathrm{CO}_{2}+7.814 \mathrm{OM}+133.318 \mathrm{SO}_{4}{ }^{2-} \\
& -6480.050 \mathrm{NO}_{2}^{-}
\end{aligned}
$$

Pandorinamorumand Pyrobotrys incurve were the species of Volvocales which was represented during summer and in the month of February and August throughout the investigation period at all stations.Pandorinaoccurs predominantly only at the point where the medium containing high organic matter was observed by Paramasivan and Sreenivasan (1981). Ankistrodesmusfalcatuswas the dominant species which is represented throughout the investigation period at all stations. The presence of Ankistrodesmus sp.in organic polluted water was reported by Ayodhya D. Kshirsagar (2013). UdayBhan Singh (2013) reported it as pollution tolerant species in sewage polluted urban eutrophic lakes and fresh water bodies which are polluted by industrial waste and sewage. Diversified Scenedesmusspecies had their presence in numerically good numbers at all stations except in the months of December and January. Chlorella vulgaris was reported in considerable number and their absence was observed during winter.

The presence of Scenedesmus sp. and Chlorella sp. indicate high organic pollution and rich nutrient status of the lake. These species are considered as indicators of highly organic polluted waters and represent eutrophic nature of the lake. This is in accordance with Verma (2010) and UdayBhan Singh (2013).

Coelostrum sp. showed summer peaks, found to be absent during winter and Crucegenia $s p$. represented by Crucigeniaqudrata, Crucigeniarectangularisand are in numerically high numbers during winter. Their presence in nutrient rich water is supported by Ansari Ekhalak (2013). According to Standards ISI 10500: 1991- Annexture-I, Scenedesmus sp., Chlorella sp. and Coelostrum sp. are found in polluted waters. Actinastrum sp. and Pyrobotrys sp. was not represented considerably throughout the investigation period and recorded maximum in monsoon especially in the month of July. Actinastrum sp. is the indicator of high organic polluted water (Ashesh Tiwari 2006), grow in nutrient rich waters (Ansari Ekhalak 2013) and it is a pollution tolerant species (Ayodhya D. Kshirsagar 2013). Micractiniumwas reported as indicator of organic pollution by Ashesh Tiwari (2006). The pollution indicators of algae were given in the form of microphotographs in Fig.1,2 and 3.

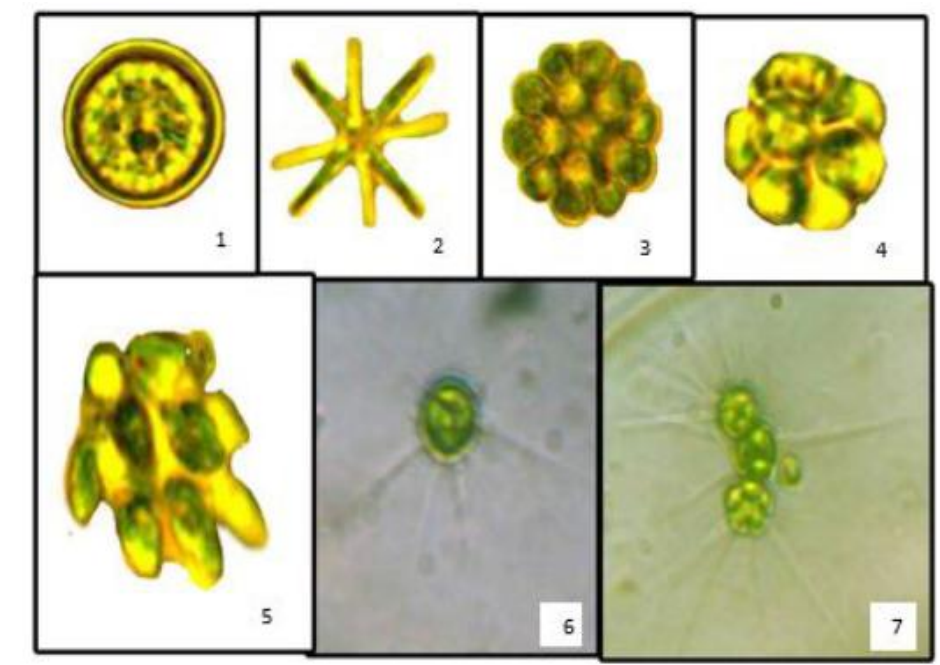

Figure.1: 1) Chlorella vulgaries Beijerinck 2) Actinastrum hantzschii. Lagerh

3) Coelastrum cambricum Archer 4) Pandorina morum 5) Pyrobotrys elongate 6) Golenkinia radiate (Chod) Wille 7) Micractinium pusillum Fresenius 


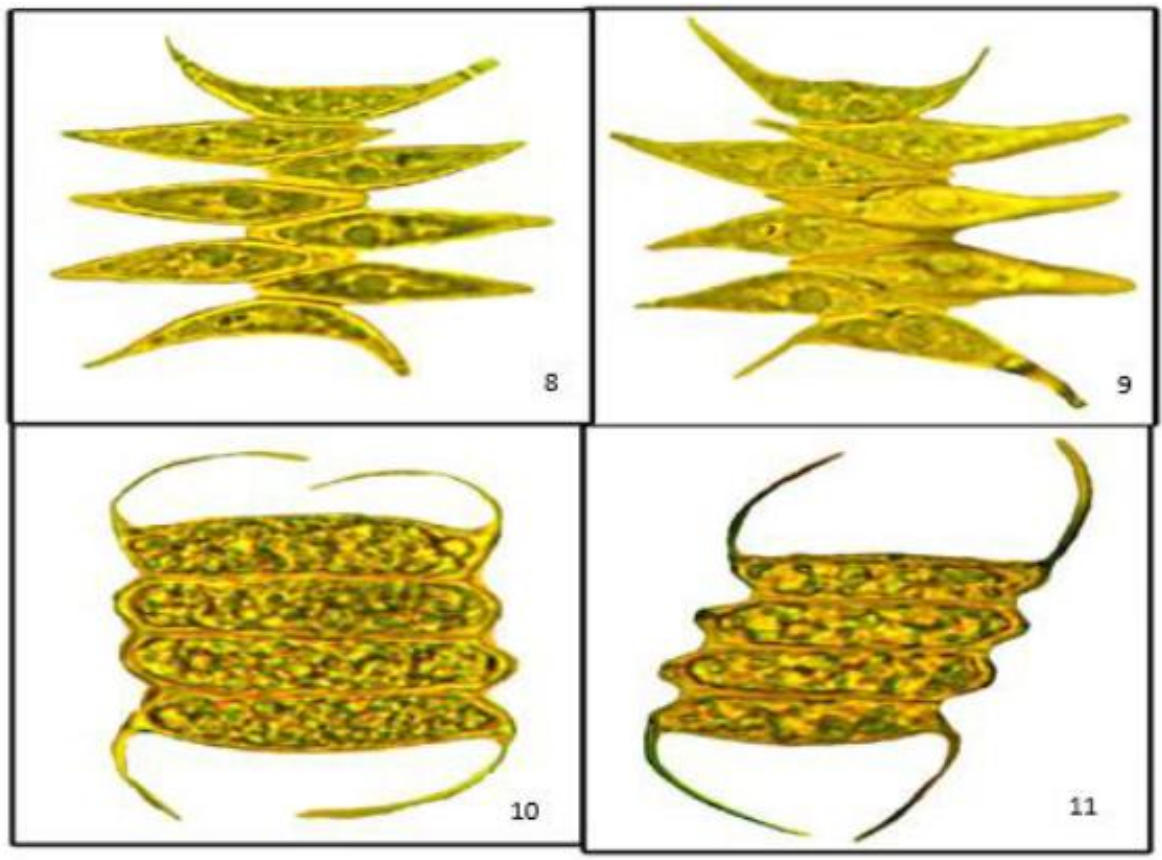

Figure.2: 8) Scenedesmus dimorpus (Turp.) Kutezing 9) S. arcuatus var. platydisca G.M.Smith 10) Scenedesmus armatus var. major G.M.Smith 11) Scenedesmus quadricauda (Turp) Brebisson var. westii G.M.Smith

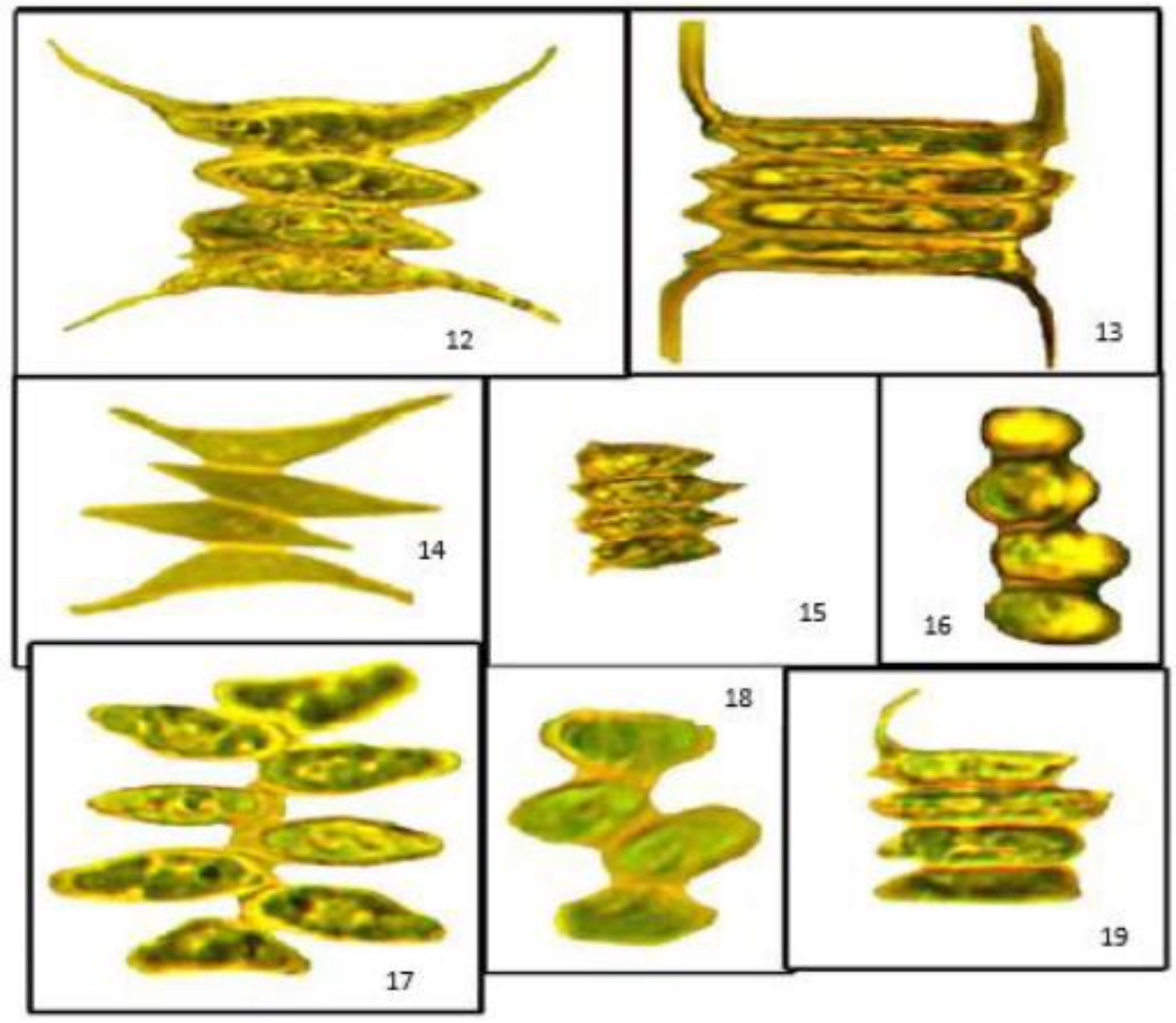

Figure.3: 12) Scenedesmus corinatus 13) Scenedesmus quodricauda (Turp.) Breb 14) S. acutus Meyen 15) S. longus (Meyen) var. noegelii (Breb) 16) S. muzzanensis Hubberpest 17) S.Bijuga (Turp.) Langerheim Var.alternans 18) S.bijugotus (Turp) Kuetz 19) s. bicaudatus (Hansqirg) 


\section{Conclusions}

The present investigation elevated the distribution and diversity of Chlorophyceae in Saroornagar Lake. The water of Saroornagar Lake is highly polluted as the physico-chemical parameters such as chlorides, total hardness, calcium, magnesium, phosphates, sulphates, BOD, total solids and total dissolved solids were higher than permissible limits and dissolved oxygen is in very low concentration when compared with the standards stipulated by WHO (1971), ISI (1982), BIS (1998) and Rawal's (1978). The evaluated physico-chemical parameters considerably influenced the growth of algae.

Chloroccocales were represented by diversified species.The species of Ankistrodesmusfalcatus, Chlorella vulgaris and Scenedesmus sp., Pandorinamorum, Actinastrumhantzchii, Pyrobotrys incurve and Micractiniumpusillum, confirm eutrophic condition of the lake and act as indicators of organic pollution and represent pollution tolerant species. Chlorella vulgaris, Scenedesmus sp., Actinastrumhantzchiiand Micractiniumpusillumare bio indicators of eutrophic lakes. The existence of Chloroccocales as bio indicators, pollution tolerant species and species representing nutrient rich medium proves polysaprobic and eutrophic condition of the lake.

\section{Acknowledgment}

Author is thankful to the management of CVR College of Engineering, Ibrahimpatnam for providing constant support and encouragement to carry out this research work.

\section{References}

[1]. Airsang R V and Lakshman H C., (2013). Diversity of Chlorophyceae related to physico-chemical parameters in Shetterlake of Navalgund, Dharwad District in Karnataka-India.Science. Research Reporter, 3(2):129-134, ISSN: 2249-2321.

[2]. Agale, M. C., Patil J. V. and Patel, N.G.,(2013).Study of seasonal variations of Phytoplankton and their correlation with physicochemical parameters of Budaki Medium Irrigation Tank,Shirpur. Dist. Dhule (M.S.) India. European Journal of Zoological Research, 2 (3):8-16., ISSN: 2278-7356.

[3]. Altaf H. Ganai and SaltanatParveen, (2014).Effect of physico-chemical conditions on the structure and composition of the phytoplankton community in Wular Lake at Lankrishipora, Kashmir.Vol.6 (1), pp.71-84, ISSN 2141-243X.

[4]. Ameetha Sinha, Baidyanath Kumar and Tanuja Singh, (2014). Water quality assessment of two ponds of Samastipur District (India).International Journal of Environmental Sciences Volume 4, No 4. ISSN 0976 - 4402.

[5]. Amirkolaie A K.,(2008).Environmental Impact of Nutrient Discharged by Aquaculture Waste on the Haraz River. Journal of Fisheries and Aquatic Science, 3: 275-279.

[6]. Amin HossainiMotlagh, Navatha K and Manikya Reddy P., (2013) a. Ecological Studies of Mir Alam Lake with Reference to Water Quality. Nature Environment and Pollution Technology. Vol. 12, No. 2 pp. 355-358, ISSN: 0972-6268.

[7]. Ansari Ekhalak, GadhiaMohini and SuranaRanjana, (2013). Phytoplanktonic Studies of Village Pond with Reference to water Quality. IJIRSET.,Vol. 2, Issue 9,ISSN: 2319-8753.

[8]. Ananthaiah, (2010). Ecological studies on temple tanks of Ananthagiri and sarpanpally project with reference to water quality.Ph.D.Thesis, OsmaniaUniversity,Hyderabad.

[9]. Ashesh Tiwari and Chauhan, S.V.S., (2006). Seasonal phytoplanktonic diversity of Kitham Lake, Agra. Journal of Environmental Biology, 27(1) 35-38.

[10]. Ayodhya D. Kshirsagar, (2013).Use of algae as a Bioindicator to determine water quality of river Mula from Pune City, Maharashtra (India), Universal Journal of Environmental Research and Technology.Volume 3, Issue 1: 79-85. ISSN 22490256.

[11]. Benjamin R, Chakrapani BK, Devashish K, Nagarathna AV and Ramachandra TV. (1996). Fish mortality in Bangalore Lakes, India. EGJ, 1(6).

[12]. Chisty, N., (2002).Studies on Biodiversity of Freshwater Zooplankton in Relationto Toxicity of selected Heavy Metals.Ph. D. Thesis submitted to M.LSukhadiaUniveristy Udaipur.

[13]. Gary E.Dillard, (2000).Pigmented euglenophyceae, Fresh water algae of south eastern United States, BibilotecaPhycologica. J Cramer., ISSN 0067-8112.,ISBN 3-443-60033-6.

[14]. Hosmani, S. P., Nagarathna and Mahadev J., (2002).Scale forming and corrosive tendencies of water in 20 lakes of Mandy district and its relation to phytoplankton, IJEP 22 (8), pp. 852-857.

[15]. John Mohammad, M., Krishna, P.V., Lamma,O.A. and Shabbar Khan, (2015). Analysis of Water Quality using Limnological Studies of Wyra Reservoir, Khammam District, Telangana, India. Int.J.Curr. Microbiol.App.Sci., ISSN: 2319-7706, 4(2): 880-895.

[16]. Kundurusurenderreddy, RezeneHabtae, Bixapathi, Manjula and Devarajam, (2014). Studies of some physico-chemical parameters of selected fresh water lakes in Andhra Pradesh, India. J BiosciTech,Vol 5(6),2014, 582-590 ISSN: 0976-0172.

[17]. Mahadev J Hosamani SP and Syed Akheel Ahmed, (2010). Statistical Multivariate Analysis of Lakes Water Quality Parameters in Mysore, Karnataka, India. World Applied Sciences Journal 8 (11):1370-1380.

[18]. Malik D.S. and ShikhaPanwar,(2014). Effect of climate changing pattern on phytoplankton biomass in Bhimtal Lake of Kumaun Himalaya. International Journal of Advanced Research, Volume 2, Issue 7, 880-894.ISSN 2320-5407.

[19]. Mishra, Sharma, S.R. and Yadav, (1992).Phytoplanktonic communities in respect to environmental conditions of lentic waters at Gwalior (MP). J.Environ.Bio. 13 (4):291-296.

[20]. Paramasivan, M. and Sreenivasan, A., (1981).Changes of algal flora due to Pollution in Cauvery River. Indian J. Environ. HIth. 23(3) 222-238.

[21]. Prescott, G.W., (1968). The algae: A Review.Houghton - Mifflin Co., Boston. 436.

[22]. Ratna V Airsang and Lakshman, H C., (2015). Seasonal Variation and Phytoplankton Diversity in Shetter Lake of Navalgund, Dharwad in Karnataka, India. International Journal of Advanced Research, Volume 3, Issue 5, 1503-1510.ISSN 2320-5407.

[23]. Ravikumar P., Mohammad AneesulMehmood, R. K. and Somashekar, (2013).Water quality index to determine the surface water quality of Sankey tank and Mallathahallilake, Bangalore urban district, Karnataka, India. Appl Water Sci., 3:247-261.

[24]. Rawal, N.C.,(1978). Quality of river waters of India reprinted from proceedings, 47 Research Session of the CPIP, HubliDharwar, Karnataka, Vol II, PP: 139-160.

[25]. Sudha Rani, P. (2004). Environmental monitoring of Hussain Sagar lake water. Ph.DThesis.O.U. Hyderabad. 
[26]. Suresh B., (2015).Multiplicity of phytoplankton diversity in Tungabhadra River near Harihar, Karnataka (India).International Journal of Current Microbiology and Applied Sciences. ISSN: 2319-7706. Volume 4 Number 2.pp. 1077-1085.

[27]. TarakeshwarSenapati, Subhabrata Ghosh and Tirthankar Mandal,(2011).Variation in phytoplankton diversity and its relation with physicochemical parameters of a semi lentic water body of Golapbag, West Bengal,India. International Journal of Current Research Vol.3, Issue,7, pp.053-055, ISSN: 0975-833X.

[28]. UdayBhan Singh, Ahluwalia, A.S., Sharma, C., Jindal, R.and R.K. Thakur., (2013).Planktonic indicators: A promising tool for monitoring water quality (early-warning signals). Eco.Env. \& Cons.19 (3). pp. (793-800), ISSN 0971-765X.

[29]. Verma R and Singh G P., (2010). Seasonal distribution of phytoplankton in Laddia Dam in Sikar district of Rajasthan.Res.J.Agri.Sci.,1(4) 